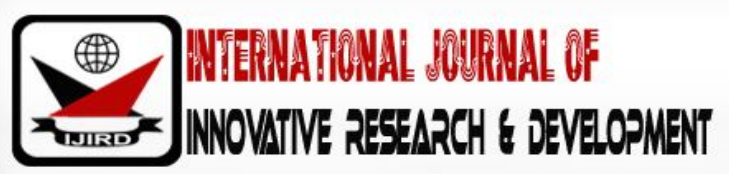

ISSN 2278 - 0211 (Online)

\section{Oil and Gas Exploitation Impact on Wildllife (The Physicsist View Point) Case Study: OML 11 and OML 52 Ikurundes Study Zone}

\author{
Nte, F.U. \\ Senior Lecturer, University of Port Harcourt, Nigeria
}

\begin{abstract}
:
Oil and gas exploitation has had presumable impact on the Niger Delta environment by Newton's law of inertia and the law of conservation of matter and energy. This study tries to establish the impact hypothetical claim from desktop and the recognizance survey through a team of participatory field experts under the Nigerian Environmental Society(NES).The Niger Delta Environmental Survey (NDES), ANOLGA Environmental Protection Committee (EPC) and local/ International press watch. This followed the claim of Elephant invasion of Ikuru town 1996 and an earlier casualty of an oil and gas seismic explorer which is of great puzzle. The impact hypothesis includes;Leh's Elephant migration theory, Iweziga's biological warfare concept,Hanson's pipeline concept. Bibito's seismic impact concept. Okujiagu's gas flare and climatic theory. Uches oil spill impact concept, Chika's Urbanization impact concept, Ujile's Geomorpho logical concept, Helen's elephant over population concept and EPC joint access road impact discovery with foreign press field assistants. A review of the hypothesis reveals that although the questionnaire respondents shows oil spill impact as the modal class, followed by the seismic noise and vibration impact. the expert investigation and state-life imagery along N04․27.368 `E007020.192` on the West, N04 27.659' E007034'709' and on the East and N04'28.936', E0070 29.642 for Ikuru is indicative that the access road was the major impact source leading to flooding in the east and siltation in the west.
\end{abstract}

Keywords: Wildlife, Exploitation, oil

\section{Introduction}

Wildlife has contributed immensely in the enhancement of human quality. It provides protein food source as games, species of research and domestication, hides and skins for the leather industry and tourism potentials for most nations. Unfortunately there has been dwindling population and species with increasing human population, industrialization and urbanization which makes the science community Powell (1995) classify them as;Endangered species, Endemic species, Mystery species, Subspecies, Totten species, Voucher specimen depending on their survival mechanism. Thus,

- Endangered Species: An often very loosely used term to suggest the species is under some danger of eventual extinction. The term has explicitly defined meanings when used in the context of particular regulations, schedules or formal lists such as the IUCN Red List ( global) or national Red Lists, or Decrees backing CITES agreements etc.

- Endemic Species: Species which is found uniquely in the geographic area under consideration. Its presence suggests there are possibly other unique features about the area's ecology or biodiversity.

- Mystery Species: A term of convenience used in this report for animals of uncertain identity, known only from hunters' descriptions and vernacular names. They may or may not eventually prove to be distinct or new species.

- Subspecies: A geographic variety of a species. In the case of geographically isolated or disjoint varieties, it is often a matter of opinion whether they are distinct enough to be considered distinct subspecies or different species. Abbreviated as ssp. (singular) and ssp. (plural).

- Totem Species: Species of cultural or traditional importance to certain families or clans which have taboos against killing or eating those species.

- Voucher specimen: A specimen which constitutes proof of a claimed and/ or distribution record.

The focus this time is the determination of elephant population and migration pattern in OML 11 and OML 52 (oil mining lease) Ikuru, Niger Delta Environmental study zone as an Environmental Evaluation Report (EER) for management. The report astonishingly shows that the oil reserve depletes to $20 \%$ the elephant population also dropped to less than $20 \%$ from early studies by Star Wood (1988) which calls for a watch. Few of the studies relating environmental pollution and wildlife are; Alexa (2006), Anderson (2005), CNN (2006), Fuggle (2004), Human Right (1999), MERCK (2007), Molles 
(2005), NFC (1996), Nwnio and Badejo (2007), Starwood (1988), SPDC (1995), WWF (2006). The expresses the increasing human impact on environment with increasing human activities and interferences.

\section{Methods}

The bulk of the research is base line information of oil and gas impact activities coupled with expertise view point, which generate a ten impact evaluation data numbered 1-10. With the help of a participatory tool box, three blocks of A, B, C representing farmers/hunters, fishermen/traders, student and elites respectively were subjected to oral and written interview.

\section{Results}

The results are shown in fig1, 2 and 3 for farmers, fishermen and elites respectively.On the part of base line; there was no respondent in favour of the biological warfare and access road impact hypothesis. There is a correlation on the elephant over population concept and urbanization impact concept across the three groups. The overwhelming majority believes in the oil spill impact which constitute the modal class in the three blocks, followed by the seismic blast impact hypothesis. The expertise view point based on field visit is as shown in fig 1,2 and 3. While the expedition search result, summary and conclusion is asreflected in 4.1-4.3.

- Which of These Hypothesis Destroy Wildlife Or Is Most True most of Elephant Invasion of Ikuru Town

\begin{tabular}{|c|c|c|c|c|}
\hline S/ No. & Table of Impact Projection Score & A & B & C \\
\hline 1 & Leh's Elephant Migration Hypothesis & 5 & 5 & 5 \\
\hline 2 & Iweziga's Biological Warfare Concept & - & - & - \\
\hline 3 & Handson's Hypothesis of Oil Pipeline Effect & - & 5 & 5 \\
\hline 4 & Bibito's Seismic Impact Concept & 15 & 10 & 10 \\
\hline 5 & Uche's Oil Spill Impact Concept & 40 & 60 & 55 \\
\hline 6 & Chiko's Urbanization Impact Concept & 20 & 5 & 5 \\
\hline 7 & Ujile's Geomorphological Concept & 5 & - & - \\
\hline 8 & Okujagus Gas Flare and Climate Impact Consent & 5 & 5 & 5 \\
\hline 9 & Helen's Over Population Concept & 10 & 10 & 10 \\
\hline 10 & Access Road Impact Concept & - & - & 5 \\
\hline \multicolumn{2}{|}{} & 100 & 100 & 100 \\
\hline
\end{tabular}

Table 1: Table of Impact Projection Score

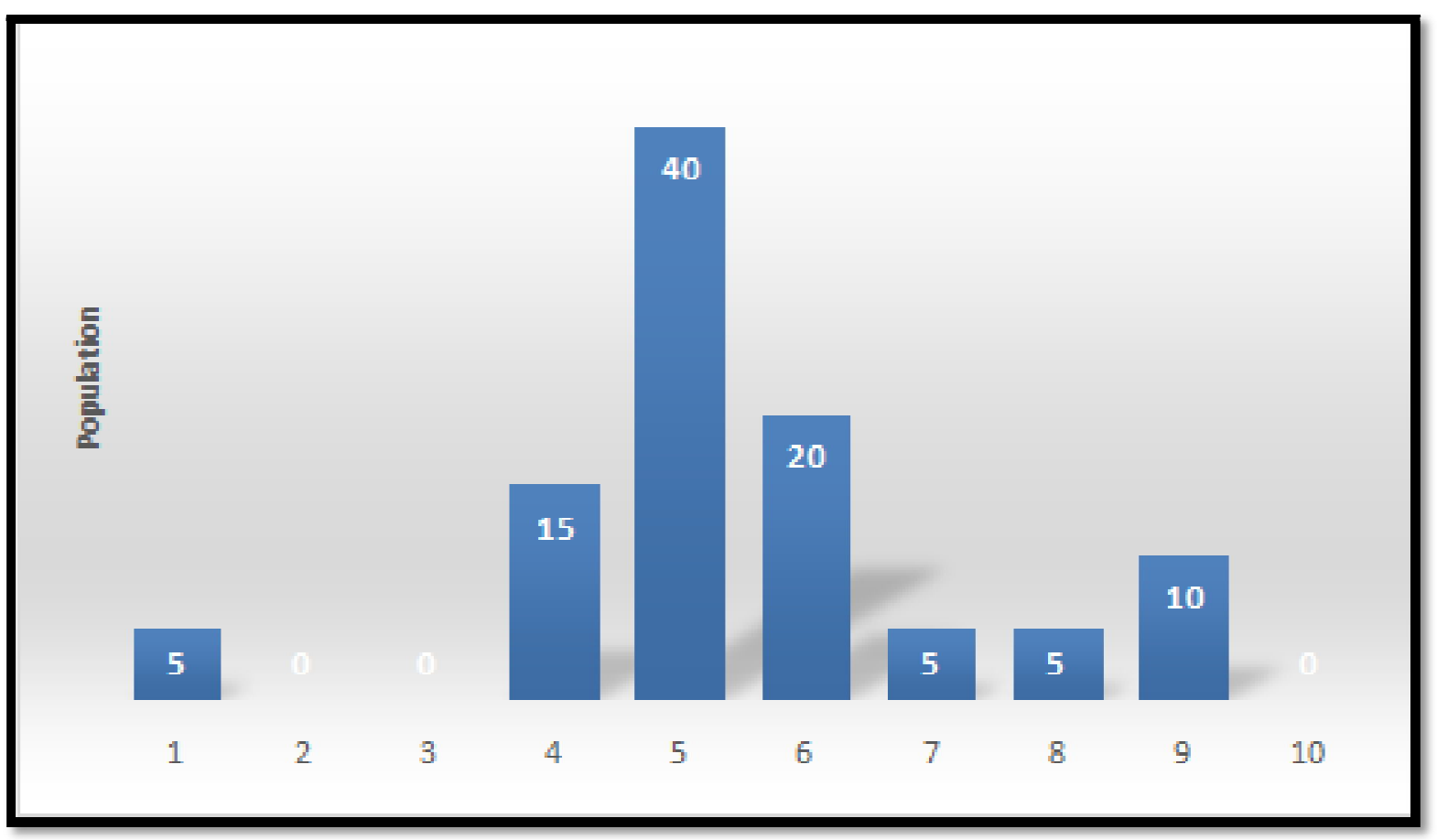

Figure 1: Oil and Gas Impact Score by Farmers and Traders 


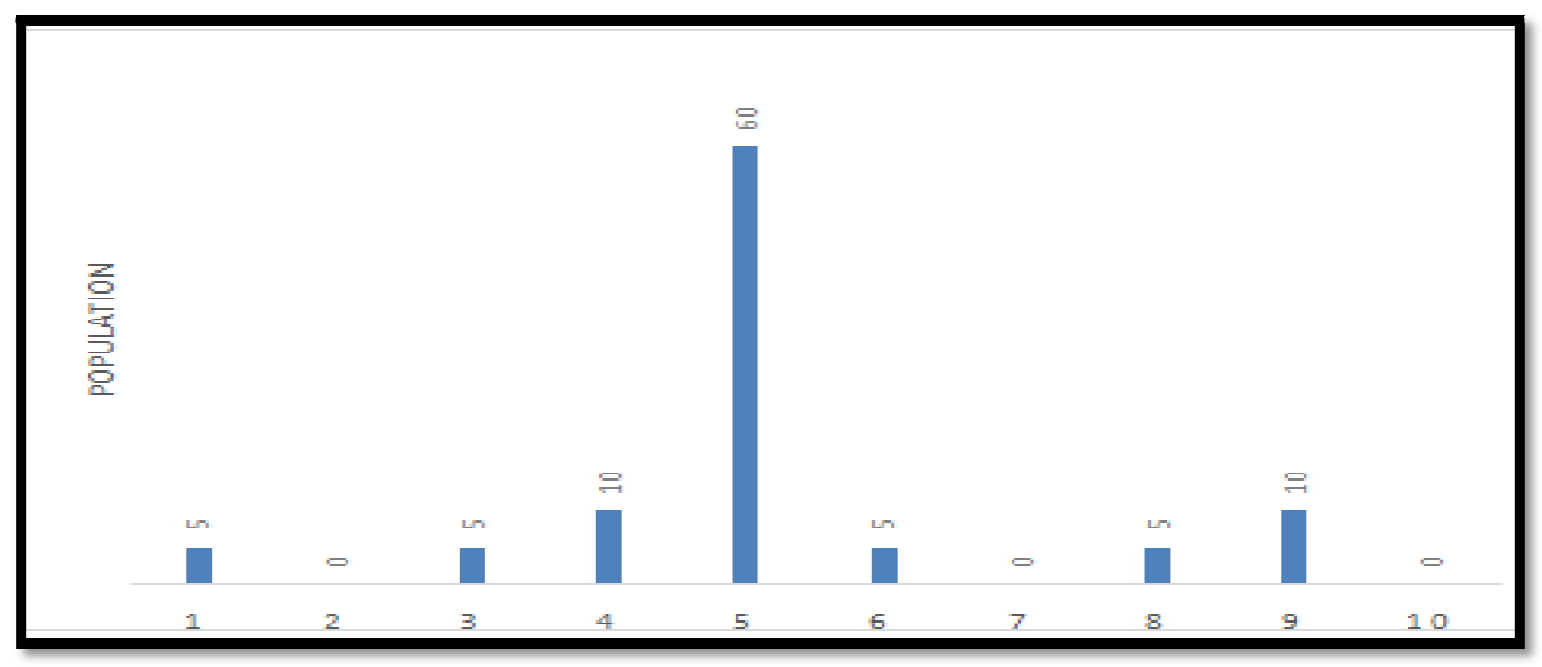

Figure 2: Oil and Gas Impact Score by Fishermen and Hunters

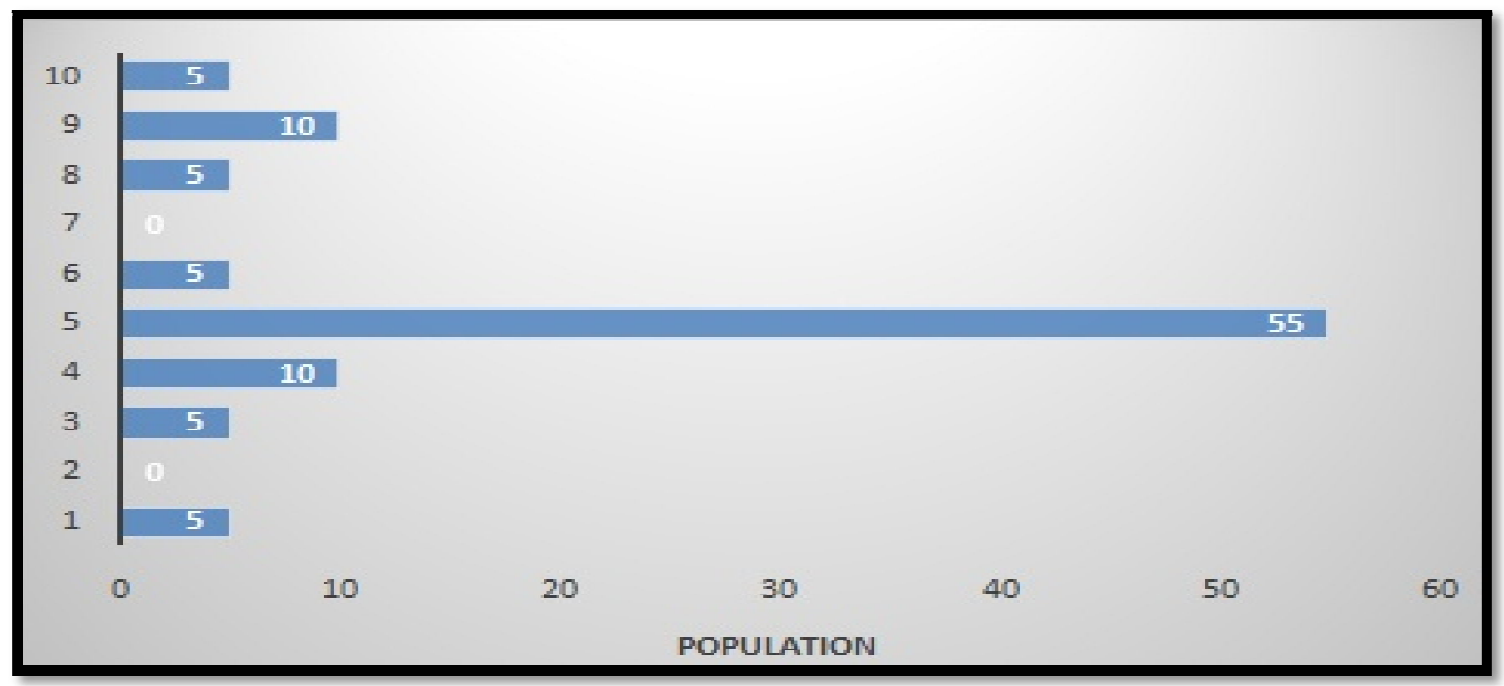

Figure 3: Oil and Gas Impact Score by Student and Elites

\subsection{Discussion}

\subsubsection{Leh's Migration Hypothesis}

Mr. Elijah Leh, a director of forest with the Rivers State Ministry of Agriculture and a close confidant of Late C.B. Powell believes that the increased surge of elephants into Andoni land could be attributed to migration from neighbouring tribes as a result of urbanization and heavy industrialization. it was believed that Okrika, Bonny and Akwa-Ibom all had elephants in the historic past but due to increased human activities, urbanization and industrialization, this luxuriant elephant species are extinct or have migrated to the Andoni barrier island where they have a high level of environmental immunity due to the terrain and the traditional occupation of the people which is sea fishing.

The other scholars agreed with him because the elephant is an herbivorous animal and like other herbivorous wildlife, has the tendency to move from place to place in search of shelter and greener pasture to graze on. It is believed that such migration can continue even within the herbs of the Andoni beach island.the record of the Late Mr. Accra Sam Jones the chairman of the Ikuru Royal Family that elephants swam across the 500 meters wide Andoni River from Oyorokoto in Andoni Local Government Area to Ifoko in Bonny Local Government Area at about 2100 hours, June 1994 and back after two days through the same track and another incident from Ebon Okpon in Ikuru across the 75 meter Ikuru creek to Minima in Opobo Nkoro Local Government Area in July 1996 at about 2200 hours and back by the following day through same track in pairs is a confirmation that Leh's claim has merit.

It is obvious that the elephant is not as curious as the monkey from wildlife studies as to just decide to swim across for a picnic. There must have been some form of pressure. By Leh's migration concept, all the neighbouring ethnic groups have lost their elephants and valuable wildlife to Andoni. Now that the Andoni wildlife is under threat, where will they migrate to? 


\subsubsection{Iweziga's Biological Warfare Concept}

Mr. Abraham Iweziga from Yenagoa Local Government Area of Bayelsa State and a staff of Rivers State University of Science and Technology claimed that what he saw in the land of Ikuru in June 1996 was an assault rather than an ordinary raid and needs a divine intervention. In his words, "I have seen elephants in Talor creek in days they existed but cannot compare it to what I am seeing in Ikuru Island forest. This elephant surge could be an invocation by some aggrieved tribal neighbors," he added.

The scholarly investigation into his claim established that people traditionally believed that thunder (Amadioha), wind, storm, bees, snakes, sea hippopotamus and elephants have in the past been used to fight enemies by magical means or through the witch doctors but these evil powers are overtaken by civilization and Christianity which should be encouraged. The lesson for the outside world is that those who want to see nature's wonders could take an advantage to visit Ikuru on studies, tourism and adventure.

\subsubsection{Hanson's Hypothesis of Oil Pipeline Effect}

Mr. James Hanson, a member of the Andoni (Obolo) Environmental Protection Committee EPC, a media practitioner and the representative of the Andoni Progressive Union in the field study claimed that the elephant's invasion was due to flooding. He attributed the flooding to the 18 Eastern bulk trunk line, which delivers over 200,000 barrels of crude oil from the Utapate flow state in Iko town of the Eastern Obolo L.G.A of Akwa Ibom State to the Bonny terminal.

Our finding was that the pipeline only showed at points where they cross or enter the sea at the manifolds' but was neatly buried in the SPDC right of way in the main island with tracks neatly maintained along the right of way. The pipe ran parallel to the natural swamps and did not obstruct the water flow significantly nor prevent wildlife from crossing. It rather exposed the wildlife to easy sighting and shooting by the hunters, which was of a short-term economic advantage. It is further suspected that apart from the local hunters, some professional elephant poachers in search of ivory take advantage of the trunk line for lack of guards, which could have a secondary impact effect.

Mr. Hanson was commended as the first to attribute the elephant surge to flooding related problem, which is scientific to believe.

\subsubsection{Bibito Seismic Impact Concept}

Mr. Maxwell Bibito of Bayelsa State, who represented Friends for the Preservation of the Niger Delta Environment FEPEN NGO in the crew, observed that Ikuru town started complaining of increased elephant surge into the area from 1994 which was shortly after major seismic activity in Oyokoroto western axis of Andoni land under Tubu field project. He claimed that the seismic activity would have caused the elephants in line with Leh's migration concept to move to the eastern axis thereby causing an increase in the population of elephants at the Ikuru environs as observed. Later studies established that herbs have totally avoided the Ilotumb an Agwu-Obolo area where there was a killing in the seismic worker and reprisal attack by some Ivory merchant who took an advantage of the law less situation to pouch.

A critical examination of this claim shows that although the elephants are bulldozers and noisy animals because of their activities, it is highly irritated by strange noise of strange frequencies from sources as chain saw, gunshots and seismic blasts, which could catalyse a migration process. The fact that Sam Owu Eleonu, a reporter of Sunray Newspaper published of elephants trampling an oil worker Mr. Tolofari to death in August 1993 while on a seismic operation have a lot to be desired in terms of regulatory compliance with the ElA which would have guided the operations and further goes to prove that the elephants were angered by the seismic blast in their historic sanctuary. The attack and killing of Mr. Friday Uboom, a seismic attendant or casual with the Western Geophysical in 1994 and the attack on Mr. Ikatele Eric Ikuru, a chain saw operator in 1995 tend to validate Bibito's claim of noise impact. A subsequent attack on Mr. Morrison Uboom in 1995, an elder brother to late Friday Uboom of the seismic crew, reference Plate 11.4.1, is enough to blame the overall aggressiveness and new trend of elephant attack on human beings to the seismic operation which has a lot of socio-economic implication on co-forest users of Ikuru town and Andoni Local Government Area in particular. It further goes to confirm the traditional claim that elephants avoid trouble as much as possible but hardly forget nor forgive when challenged.

\subsubsection{Mr. Uche Oil Spill Impact Concept}

Mr. Uche Ogarachu a graduate of Environmental Management who was on the crew as a research student, gathered from oral evident that there was a major oil spill along the eastern bulk line which delivers 200,000 barrels of crude oil per day from the Otapiti flow station to the Bonny terminal. According to oral sources from Mr. Azu, the oil spill was in 1993/94 and could cause the elephants to migrate off the spill site around Oyorokoto western axis to Ikuru eastern flank thereby increasing their numbers and antagonism on a competitive basis.

The claim looked logical as animals in oil spill areas have the tendency to migrate off the site if they are not already trapped dead in the oil seal due to locomotion and respiratory related problems or food poisoning effect. The study did not record the hydrocarbon level because of the vastness of the area and the fact that oil spill has turned to be a continuous discharge from production process and is difficult to pinpoint one company over hydrocarbon deposit because the spill from a source cuts 
across regions.

In most cases it is the local cleanup of tidal influence, evaporation and. precipitation run off that disperse the oil.

\subsubsection{Chika's Urbanization Impact Concept}

Mr. Chika Igwe a graduate of Environmental Management on the crew claimed that infrastructural expanse in Ikuru town and other Andoni towns has caused an encroachment into the games sanctuary which is likely causing the antagonism and visitation to people's compounds.

The study group agrees with Chika in terms of increasing human population and increasing inter-forest use but the level of expansion in terms of infrastructure is still slow. Out of the seventeen swamps documented by the EPC, the infrastructural development has just crossed three of the swamps. Besides elephants are herbivorous and have no business with infrastructure as to justify their movement into towns, schools and church premises. There was a documentation that an elephant gave birth at late Apollus Ofik's compound in June 1996 thereby keeping the residents indoors for the baby to wean strong enough to move back. Our finding revealed that late Ofik's house is close to the swamps and the Ebon Okpon mission is on their new hack to the creek for nympa palm, which is more of elephant encroachment than human advancement.

\subsubsection{Ujile's Geo-Morphological Concept}

One of the environmental experts Mr. Ujile Meshak onboard the study crew, a member of the Nigerian Environmental Society NES postulated that the apparent elephant surge to Ikuru could be because of the constriction of the shark shaped barrier island along the Ikuru axis. He observed that whereas the rest part of the sanctuary island has between $5 \mathrm{~km}$ to $7 \mathrm{~km}$ width, the said Ikuru zone has between $2.5 \mathrm{~km}$ to $3.5 \mathrm{~km}$ width which could induce more pressure if a normal traffic rate is to be followed.

His claim by the joint study team was found to be mathematical but from animal psychology standpoint cannot make the elephant to leave the bush into Ikuru town. Furthermore, it is estimated by survey that the area has about 50 herds of elephants with each about 2.5 meters full grown length. All the 50 herds put together can just give 125 meters length which is far from covering the 3000 meters Ikuru channel and cannot also account for the increased flooding as the area has the least available area surface for precipitated water to accumulate.

\subsubsection{Okujagu's Gas Flare and Climate Hypotheses}

On a review of preliminary filed report by environmental protection committee, is EPC Professor Charity Okujagu of the Physics Department, University of Port Harcourt remarked the omission of gas flare. she stressed that gas flare emit the $\mathrm{NO}_{\mathrm{x}}, \mathrm{SO}_{\mathrm{x}}, \mathrm{CO}_{\mathrm{x}} \mathrm{NH}_{4}$ and suspended particulate matter SPN which are NOR acid rain precursors and greenhouse gases which could affect climate, reduce visibility, cause heat island and photochemical smog effect and photo periodicity on flora as well as greater skin penetration on faum by radiation in the form.

$$
\hat{\jmath}=\sqrt{\frac{2}{2 \pi f \sigma \mu}}
$$

Where; $\hat{\jmath}=$ depth of skin penetration

$\mathrm{f}=$ frequency of the wave

$\sigma=$ conducitivity of the media

$\mu=$ permeability

On a review by EPS hypothesis was correct but sad enough most of the gas flare are near shore and offshore, the only flare on land which is the opbo south by SPDC at Okoro-Oboile was temporarily shot down. Thestudy recommends further investigation of the high frequency noise and radiation. There is no drought that the gross emission on effect agriculture and climate.

\subsubsection{Helen's Overpopulation Concept}

Miss Helen Okon, one of the camera persons believes that the surge was due to overpopulation considering the amount of years the elephant has co-existed in the' land of Andoni and tire two cases reported of the elephants giving birth in people's compounds. Thescholarly report on her claim observed that elephants have a gestation period of 2 years and 5 years to wean the baby and will need at least 10 years interval to give birth to just one calf which makes it difficult to talk of over breeding. Furthermore, the research has put the survey number of about 50 herds to be in equilibrium with the forest size of $124 \mathrm{~km}^{2}$ and has been maintained over the years by three study reports.

\subsubsection{Survey Specifies Phase II}

Access road impact discovery Sam Alokoy, reporter news watch, Barry Morgan, correspondence upstream and Nte, F.U. EPC. Secretary.

Unlike the other survey which was randomly conducted; this time a block was mapped out for a detailed survey cutting a transept across the forest to the Atlantic shore along the ancient forest track used in transporting food to the beach 
for fishermen. Unfortunately, because the root has been abandoned for over 20 years long, we wrestled against high flooding, leeches, tsetse flies, cobwebs and creping creatures, stumbling with dead logs and slippery stumps of roots with just an occasional glimpse of the sun's rays at day time. As we stumbled through the forest with lots of uncertainty and fears of the worst, we encouraged ourselves in the Lord with the following Bible scriptures; 1 Samuel 30:6, Psalm 23:4, Isaiah 43:1-3, particularly the empowerment of Genesis 1:28 which stipulated that we are made in the image of God and given the authority to subdue and manage all the other things God created, "including the elephants, python, hippopotamus and crocodile". As we pondered on those passages, we found our hopes sailing through with joy until we got at the Atlantic shore. We documented 13 swamps in all across the forest as against 20 by oral claim. It was to us like ferry-tales of visiting a Ghost village and coming back alive. You can imagine the happiness of survival.

\subsubsection{Challenges to Phase II Studies and Mobilization}

On a desk review, the hypothesis could not justify the elephant invasion of Ikuru town and call for more studies but the idea of another field study looked almost impossible. This was because some members of the study crew have long been withdrawn. The EPC allowance of \#100 per day denied the members, the EPC secretary's job abruptly terminated and the supervisor of his $\mathrm{PhD}$ thesis unceremoniously withdrawn with lots of discouragement from some respected quarters, calling for a withdrawal from the study for some apparent better offer in some other job sector which was highly tempting. Someone even died without their goal of thisreport while some of us suffered military detention at Aso Rock in Bori Camp for mistaken identity which made us more robust and determined resolute to break the wall.

\subsubsection{Projected Gains of the Study}

We are glad that the very ancient track road we passed through as the valleys and shadows of death has been turned to concrete road and used as a boundary by Mac AuthorFoundation study report to delineate the elephant free zone to the east towards the mouth of the Imo Rivers where the elephants strive best in the dry seasons. The closest towns Okorobo Ille and Queens town are also attraction zone while Ikuru town the mother by court verdict dual roles as a projected Naval Base, has a free concrete tarred road for tourism, carnival and business by sea men.

\subsubsection{Erosion Disaster in the Zone}

On arrival at the beach, we continued to the east terminal town, Ibot Okpon Obolo to pick stories of recent sea turtle and sea hippopotami movement and we were shocked at the rate of erosion at Ibot Okpon Obolo on the mouth of the Imo River. The erosion has reduced the wildlife sanctuary and we wished it could be integrated as a satellite development scheme of the ALSCON export project in that region which was lost out due to what the research considered as western conspiracy to encourage continuous export of raw material in exchange for processed goods with additional job creation opportunities outside.

\subsubsection{Discovery of Otaka-Ikpo Rig Access Road}

We informed the fishermen that we hoped to zero back to Ikuru West and were very joyful to find ourselves on a fairly good road after crossing just two swamps. It was a big discovery to us but to the forest users, it was the new commercial route for the people of Okede and iKuru town, courtesy of Shell Petroleum Development Company, SPDC one of the multinational firms in 1975. As we walked down the road, they took us through what they referred to as Otaka Ikpo III, II, I wells and continued through an old bailey bridge to an abandoned helipad at Uko-Efekk.

\subsubsection{Validating Study Report}

The EPC account of the Access road Impact generated a lot of curiosity and interest as this was about the first time a report is claiming that infrastructural development could have a negative environmental consequence. Key among the visitors to the site was Mr.Sam Alokoye of NewsWatch, Mr.Nkereuwem Akpan of Sunray Newspaper and Mr.Barry Morgan of the Oil and Gas International Newspaper, the UPSTREEM team, and the NDES team under the leadership of Mr. Patrick Erasmus, three other experts who camped at the Ikuru site from September to December 1997. They have equally submitted their report to the proponent awaiting publication. Unfortunately, none of these had any external inference to validate the Ikuru access road report as scientific, which leaves a gap for the EPC to fill.

\section{Summary and Conclusion}

\subsection{Technical Discovery on Access Road}

In the course of the return journey, we observed that the new road was a sand filling of the swamps to create an access road for the rig to come. This led to blocking of natural drainage in part which resulted to excessive flooding on the eastern flank and silting on the western flank. We also discovered that most timber resources of the west had wilted and resisted natural resuscitation for over 20 years while the level of flooding in the east was such that no mammal could survive in. There were hardly noticeable signs of Fauna at the impacted western swamps which was just naked with thousands of 
wilted timbers still standing out as relics of the old glory. The sparse forest covering at tire immediate back of ikuru town became the last resort for elephant's migration to take shelter. This was sustained by drainage through the Bailey bridge. The elephants visited the streets and homes in search of solid ground to rest and descended on the few farmlands due to hunger. They trespassed the village in search of more farmlands for food and even crossed the Ikuru creek to Minima in Opobo Nkoro local government area. The fact that the exotic nympa palm along the creeks was now a new found love of food is an act of hunger and explains why the elephants bad to walk across the town. The overall socio-economic implication in terms of loss of food crop, raffia palm, palm estate, timber resources and antagonism with co-forest users are obvious reason that drove the Andoni fisher men across the coast of Nigeria and West Africa with more hardship on landlord issues.

\section{Recommendation}

\subsection{Comparative Study and Appeal}

Comparative study from friends for the preservation of Niger Delta FEPEN NGOand EPC documented through participatory study in some part of Bayelsa State that Andoni Ikuru mistake repeated in 1995 along the Gbaran Deep oil field access road belonging to the sameSPDC(Shell Petroleum Development Company) who constructed the road through $219 \mathrm{~km}^{2}$ proposed Gbaran games reserve bounded by Orashi River on the northern end, iaylor creek on the western end, Ekolo River (creek) on the southern end and Yenagoa creek on the eastern end. The road was acquired through sand-filling without proper drainage consideration leading to siltation on the west end and flooding in the east. But for a quick intervention team due to green peace and save earn which led to the opening up of the drainages to restore the natural water distribution balance, it would have led to several losses as is the Ikuru/ Andoni case that had nobody to plead their case. That the woes of Andoni ecology was the SPDC access road impact which has not been addressed for over forty years of oil and gas exploitation in the region and is the demand of the uninformed for proper investigation and reparation by the appropriate law of justice. In same way the Ogoni issues attracted UNEP attention.

\section{References}

i. Alexa. "Oil and Nigeria." Nigeria-Planet.Com. 2006. Retrieved on 21 May 2007. http:// www.nigeria-planet.com/ OilAnd-Nigeria2.html>.

ii. Anderson, I. 2005. Niger River basin: A Vision for Sustainable Development. The World Bank: Washington D.C. Pp. 1131

iii. CNN. 2006. Pipeline Explosion Kills at Least 200. Retrieved May 29. 2007, from http:/ / www.cnn.com/ 2006/ WORLD/ africa/ 12/ 26/ nigeria.blast/ index.html

iv. Fuggle. R.F. 2004. Africa Environment Outlook Lake Victoria: A Case Study of Complex Interrelationships. United Nations Environment Programme. Pg. 75-85

v. Human Rights Watch. 1999. The Price of Oil. Retrieved November 9.2007 from http:/ / www.hrw.0rg/ rep0rts/ 1999/ nigeria/ [1](http:/ / www.hrw.0rg/ rep0rts/ 1999/ Nigeria/ )

vi. MERCK. "Indigenous Plants to the Rescue." Science in Africa. Feb. 2002. Retrieved on 21 May 2007 <http:// www.scienceinafrica.co.za/ 2002/ february/ oil.htm>.

vii. MERCK. "Indigenous Plants to the Rescue." Science in Africa. Feb. 2002. Retrieved on 21 May 2007くhttp: www.scienceinafrica.co.za/2002/ february/ oil.htm>.

viii. Molles Jr. M.C. 2005. Ecology Concepts and Applications. 3rd Edition. McGraw-Hill Companies Inc. Pg. 93-94.

ix. NFC. "Nipa Palm Utilization Project." Nigerian Conservation Foundation.1996. $\quad$ Retrieved $\quad$ on $21 \quad$ Mal 2007くhttp:/ / www. afrieanconservation.org/ ncftemp/ nipa.html>.

x. Nwilo, Peter C., and Olusegun F. Badejo. comps. Impacts and Management bf Oil Spill Pollution Along the Nigerian Coastal Areas. Retrieved on 20 May 2007 \ttp:// www.fig.net/ pub/ fipub/ pub36/ chapters/ chapter 8.pdf>.

xi. Nwilo. Peter C., and Olusegun T. Badejo, comps. Impacts and Management of Oil Spill Pollution Allong the Nigerian Coastal Areas. Retrieved on 20 May 2007 <ttp:/ / www.fig.net/ pub/ figpub/ pub36/ chapters/ chapter_8.pdf>.

xii. Nwilo. Peter C. and Olusegun T. Badejo. epmps. Impacts and Management of Oil Spill Pollution Along the Nigerian Coastal Areas. Retrieved on 20 May 2007 http:/ / www.fig.net/ pub/ figpub/ pub36/ chapters/ chapter_8pdf>.

xiii. Okereke, J.N., S O. Oiekezie. and K O. Obasi, comps. Microbial Flora of Oil- / Spilled Sites in Agbema. Imo State. Nigeria. Vers. Vol. 6 (8). 16 Apr. 2007. Academic Journals. Retrieved on 21 May 2007.〈http:/ / www.academicjournals.org/ AJB/ PDF/ pdf2007/ 16Apr/ Okereke\% 20et\%20al.pdf>.

xiv. Shell International Petroleum Company. Developments in Nigeria (London:March 1995).

xv. World Wildlife Fund. 2006. Fishing on the Niger River. Retrieved 10 May 2007 from http:/ / www.panda.org/ news_facts/ multimedia/ video/ index.cfm?uNewsID=61121 